\title{
MEMPERTIMBANGKAN AMANDEMEN KONSTITUSI (KAJIAN CALON PRESIDEN PERSEORANGAN DARI ASPEK KEDAULATAN RAKYAT DAN KONSTITUSIONALISME)
}

\author{
Rudy \\ Fakultas Hukum Universitas Lampung. \\ Email: rudy.1981@fh.unila.ac.id
}

\begin{abstract}
People's expectations of the political party the less, as seen in the decline of voter participation and cynicism on the performance of the elite in the executive and legislative branches. Of his own political party, does not appear seriousness introspection headed clear modern party program and the recruitment of cadres. In the midst of apathy towards political parties at this time, and the approach of the national public needs to elect a president who can fix the state of the nation and state, discourse of individual presidential candidates should be encouraged through mechanisms that reflect the state of law based on democratic constitution. Through the constitutional process, the results will reflect the development of constitutionalism systematic, holistic, and focused and not constitutionalism sporadic development and pragmatic.
\end{abstract}

Keywords: Amandement, Sovereignty of the People, Constitutionalism

\section{abstrak}

Harapan rakyat terhadap partai politik kian rendah sebagaimana terlihat pada kemerosotan partisipasi pemilih dan sinisme atas kinerja elite di eksekutif dan legislatif. Dari partai politik sendiri, tidak tampak kesungguhan melakukan introspeksi beranjak menuju partai modern yang jelas program dan perekrutan kadernya. ${ }^{1}$ Di tengah-tengah apatisme terhadap partai politik saat ini, dan semakin dekatnya hajat nasional untuk memilih presiden yang bisa membenahi keadaan bangsa dan negara, wacana calon presiden perseorangan harus didorong melalui mekanisme yang mencerminkan negara hukum berdasarkan konstitusi yang demokratis. Melalui proses yang konstitusional, hasil yang didapat akan mencerminkan pembangunan konstitusionalisme yang sistematik, holistik, serta terarah dan bukan pembangunan konstitusionalisme yang sporadis dan pragmatik.

\footnotetext{
${ }^{1}$ Suwidi Tono, Jalan Terjal Demokrasi, Harian Umum Kompas, 23 Januari 2013
} 
Kata kunci: Amandemen, Kedaulatan Rakyat, Konstitusionalisme

\section{A. Pendahuluan}

Masa peralihan Indonesia menuju suatu cita demokrasi merupakan salah satu proses yang menjadi tahapan penting perkembangan Indonesia. Salah satu aspek yang menjadi bagian dari proses peralihan Indonesia menuju cita demokrasi adalah terjadinya perubahan di bidang ketatanegaraan yang di antaranya mencakup proses perubahan konstitusi Indonesia tahun 1945 (UUD 1945). Undang-Undang Dasar 1945 telah mengalami perubahan-perubahan mendasar sejak dari Perubahan Pertama pada tahun 1999 sampai ke Perubahan Keempat pada tahun $2002^{2}$.

Perubahan itu sebagai wujud pelaksanaan gagasan check and balances antar pelaksana ketiga bidang kekuasaan negara. Sebelum Amandemen UUD 1945, Majelis Permusyawaratan Rakyat (MPR) berkedudukan sebagai lembaga tertinggi negara yang melaksanakan kedaulatan rakyat sepenuhnya, namun setelah Amandemen UUD 1945, kedudukan MPR tidak lagi sebagai lembaga tertinggi negara, melainkan sebagai lembaga negara yang juga sama seperti lembaga kenegaraan lainnya. ${ }^{3}$

Perubahan ketatanegaraan ini juga berakibat pada pemilihan presiden secara langsung yang sebelumnya pemilihan presiden ini dilakukan oleh MPR. ${ }^{4}$ Para perumus perubahan UUD 1945 dengan mendasarkan diri pada sistem demokrasi perwakilan akhirnya merumuskan pemilihan langsung oleh rakyat dengan paket calon yang diajukan oleh Partai Politik. Selengkapnya pasal pemilihan presiden secara langsung adalah sebagai berikut:

\section{Pasal 6A}

(1) Presiden dan Wakil Presiden dipilih dalam satu pasangan secara langsung oleh rakyat. ***)

(2) Pasangan calon Presiden dan Wakil Presiden diusulkan oleh partai politik atau gabungan partai politik peserta pemilihan umum sebelum pelaksanaan pemilihan umum. ***)

(3) Pasangan calon Presiden dan Wakil Presiden yang mendapatkan suara lebih dari lima puluh persen dari jumlah suara dalam pemilihan umum dengan sedikitnya dua puluh persen suara di setiap provinsi yang tersebar di lebih dari setengah jumlah provinsi di Indonesia, dilantik menjadi Presiden dan Wakil Presiden. ***)

\footnotetext{
2 Jimly Asshiddiqie, "Struktur Ketatanegaraan Indonesia Setelah Perubahan Keempat UUD Tahun 1945”, Makalah Disampaikan Pada Seminar Pembangunan Hukum Nasional VIII Denpasar, 14-18 Juli 2003.

${ }^{3}$ Pasal 1 ayat (2) Perubahan Ketiga UUD 1945.

${ }^{4}$ Pasal 6 ayat (2) UUD 1945 sebelum perubahan mengatur bahwa Presiden dan Wakil Presiden dipilih oleh Majelis Permusyawaratan Rakyat dengan suara yang terbanyak.
} 
(4) Dalam hal tidak ada pasangan calon Presiden dan Wakil Presiden terpilih, dua pasangan calon yang memperoleh suara terbanyak pertama dan kedua dalam pemilihan umum dipilih oleh rakyat secara langsung dan pasangan yang memperoleh suara rakyat terbanyak dilantik sebagai Presiden dan Wakil Presiden. ****)

(5) Tata cara pelaksanaan pemilihan Presiden dan Wakil Presiden lebih lanjut diatur dalam undang-undang. $* * *$ )

Ketentuan mengenai pemilihan langsung presiden sebagaimana yang dianut oleh UUD 1945 sangat tepat jika dikaitkan dengan basis legitimasi dalam sistem pemerintahan presidensial, yaitu rakyat. Pemilihan langsung inipun jika dilihat dari risalah perubahan UUD 1945 merupakan hasil perdebatan yang panjang oleh perumus amandemen UUD 1945. Konsep demokrasi perwakilan yang kuat di tim perumus akhirnya menghasilkan kata final perumusan pengusulan paket calon presiden dan wakil presiden oleh partai politik atau gabungan partai politik. Nuansa penguatan demokrasi melalui penguatan partai politik menjadi wacana yang mengemuka dalam proses perumusan perubahan UUD 1945 tersebut sehingga suara minoritas mengenai pengusulan calon presiden perseorangan tidak bergabung. ${ }^{5}$

Dinamika ketatanegaraan dan politik akhirnya menimbulkan dominasi partai politik yang bisa disebut menjurus ke oligarki politik. Di tingkat pemilukada, wacana calon kepala daerah dari jalur independen mendapatkan keabsahan konstitusional setelah Mahkamah Konstitusi membuka calon kepala daerah dari jalur perseorangan dengan memperluas penafsiran demokratis dalam UUD 1945. Keadaan oligarki politik yang cenderung semakin kuat dan penafsiran Mahkamah Konstitusi terhadap pengertian pemilihan yang demokratis kemudian menelurkan gagasan calon presiden dan wakil presiden dari jalur perseorangan. Wacana tersebut menurut beberapa pengamat akan mengurangi dominasi partai politik sebagai sarana perekrutan politik di tingkat nasional, bahkan dapat mengurangi oligarki parpol. Alasan lain adalah sistem pemerintahan presidensial tidak berjalan efektif karena pemerintahan terkesan disetir oleh kepentingan parpol koalisi. Dengan adanya calon perseorangan, diharapkan sistem presidensial bisa berjalan efektif.

Tulisan ini secara khusus akan mengupas mengenai wacana calon presiden perseorangan dari sudut konstitusionalisme Indonesia yang mencakup kedaulatan rakyat, kedaulatan hukum, dan supremasi konstitusi. Tulisan ini akan berusahan menjawab pertanyaan penting bagaimana aspek hukum dan konstitusi mengenai calon presiden perseorangan di Indonesia.

\footnotetext{
${ }^{5}$ Lihat Mahkamah Konstitusi, Naskah Komprehensip Perubahan Undang-Undang Dasar Negara Republik Indonesia 1945, 2008, Buku IV Kekuasaan Pemerintahan Negara Jilid 1, Sekretariat Jenderal dan Kepaniteraan Mahkamah Konstitusi.
} 


\section{B. Pembahasan}

\section{Kedaulatan Rakyat, Kedaulatan Hukum, dan Pemilihan Langsung}

Kedaulatan adalah konsep mengenai kekuasaan tertinggi dalam negara. Dalam hubungannya dengan Capres perseorangan yang menjadi kajian dalam tulisan ini, terdapat dua konsep kedaulatan yang penulis perlu sampaikan yaitu: Kedaulatan Rakyat dan Kedaulatan Hukum.

Teori kedaulatan rakyat bertolak dari persepsi bahwa sesungguhnya rakyatlah yang memegang kekuasaan tertinggi dalam negara bukan penguasa. Karena penguasa cenderung mempertahankan dan memperluas kekuasaannya, maka perlu ada pembatasan-pembatasan atas kekuasaan yang diserahkan kepada penguasa itu. Dalam teori ini pemerintah menyerahkan kebebasan hak serta wewenangnya kepada rakyat seluruhnya, sehingga terjadi perubahan dari suasana hidup alamiah menjadi kehidupan bernegara. Gagasan bahwa rakyat yang berdaulat dapat disimpulkan bahwa yang terbaik untuk masyarakat adalah apa yang dianggap baik oleh semua orang yang merupakan rakyat. Tokoh-tokoh teori kedaulatan rakyat adalah John Locke, Montesquie, dan Jean Jacque Rosseau.

Kekuasaan negara tidaklah tak terbatas. Kekuasaan yang dimiliki negara datang dari para individu yang membuat perjanjian, bukan dari Tuhan seperti teori Hobbes. Jika Hobbes berpendapat bahwa individu-individu senantiasa bertikai, Locke sebaliknya mengatakan bahwa manusia itu pada awalnya hidup dalam kedamaian. Situasi ini baru berubah setelah manusia mulai diperdayai oleh materi, termasuk masalah tanah. Untuk melindungi hak milik inilah yang membuat para individu bersepakat mendirikan negara. Hak milik ini meliputi pula hak-hak asasi manusia yang paling utama, seperti hak untuk hidup dan kebebasan. Para individu yang mengadakan perjanjian tersebut kemudian menyerahkan hak-haknya kepada negara, dan sebagai konsekuensinya, pembatasan kekuasaan negara harus dicantumkan dalam suatu naskah dasar perjanjian masyarakat. Pembatasan kekuasaan negara ini dimuat dalam konstitusi. John Locke membagi kekuasaan ini menjadi 3 fungsi, yaitu legislatif, eksekutif, dan federatif (hubungan luar negeri). Menurut Locke kekuasaan yang tertinggi ada di tangan legislatif, yaitu parlemen.

Pembagian kekuasaan ini (negara) dari Locke dikembangkan oleh Montesquieu dengan doktrin trias politica. Dalam doktrin ini, menurut Montesquieu, ketiga jenis kekuasaan harus terpisah, baik mengenai fungsi (tugas) maupun mengenai alat perlengkapan (organ) yang melaksanakannya. Ketiga jenis kekuasaan tersebut mencakup:

1. Kekuasaan Legislatif, dilakasanakan oleh suatu badan perwakilan rakyat;

2. Kekuasaan Eksekutif, dilaksanakan oleh pemerintah; dan

3. Kekuasaan Yudikatif, dilaksanakan oleh badan peradilan. 
Sementara itu, Jean Jacques Rousseau merupakan ahli hukum tata negara yang menentang keras absolutisme negara. Menurutnya:

In the ideal social collectivity, the opinions, interests, and preferences of individuals are amalgamated into the "general will," which is the only legitimate sovereign authority-legitimate because it contains, and transcends, the wills of the individual members. In such a regime, laws that are in accordance with the general will are not coercive, and they are never unjust, for no one can coerce or be unjust to one self.

Setiap individu memiliki kehendaknya sendiri, tetapi di sisi lain juga ada kepentingan para individu untuk menjaga hubungan sosial. Hal terakhir ini disebut kehendak umum atau general will (volonte generale). Tugas negara adalah menjalankan kehendak umum dari rakyat itu. Ini berarti kehendak rakyat identik dengan kehendak negara. Rakyat yang memiliki negara, bukan penguasa. Rakyatlah pemilik kedaulatan.

Selain volonte generale terdapat pula volonte de tous yang menurut Rosseau hanya dipergunakan oleh rakyat seluruhnya sekali saja waktu Negara hendak dibentuk melalui perjanjian masyarakat. Maksud volunte de tous ini untuk memberikan dasar agar supaya Negara dapat berdiri abadi, karena ini merupakan kebulatan kehendak, dan jika Negara itu sudah berdiri, pernyataan setuju tidak bisa ditarik kembali. Untuk selanjutnya volunte de tous ini sudah tidak dipakai lagi, karena jika setiap keputusan harus dilakukan dengan suara bulat, maka roda pemerintahan tidak dapat berjalan. ${ }^{6}$

Meskipun demikian, Rosseau tidak menyetujui jika penyerahan kewenangan rakyat pada penguasa atau negara adalah wujud dari penyerahan hak dan kebebasan belaka. Kontrak sosial bermakna penyerahan untuk mewujudkan kebebasan itu sendiri. Kontrak sosial menghidupkan tatanan pemerintahan dan struktur kenegaraan yang teratur sekaligus menepis kegundahan filosofis yang mendera rakyat di era state of nature. ${ }^{7}$

Di Indonesia, perdebatan mengenai gagasan kedaulatan rakyat sudah mengemuka jauh sebelum penyusunan UUD 1945. Baik Soekarno melalui majalah Fikiran Ra'jat dan Soeloeh Indonesia Moeda, maupun Hatta melalui majalah Daoelat Ra'jat sudah mengemukakan gagasan kedaulatan rakyat yang meliputi demokrasi politik dan demokrasi ekonomi. ${ }^{8}$ Pada perkembangannya, prinsip kedaulatan rakyat inilah yang kemudian melahirkan konsep demokrasi yang menempatkan rakyat sebagai pemegang

\footnotetext{
${ }^{6}$ Lihat Moh. Kusnardi dan Harmaily Ibrahim, Hukum Tata Negara Indonesia, Ctk Ketujuh, Pusat Studi Hukum Tata Negara (Jakarta: FH UI dan CV Sinar Bakti, 1988), hlm. 126.

${ }^{7}$ Fahri Hamzah, Negara Pasar dan Rakyat, Faham Indonesia, 2010, hlm. 26-27.

${ }^{8}$ Lihat Jimly Asshiddiqie, Gagasan Kedaulatan Rakyat dalam Konstitusi dan Pelaksanaannya di Indonesia,(PT Ichtiar Baru Van Hoeve, 1994), hlm. 2.
} 
kedaulatan. Dengan berkembangnya negara dan dunia, prinsip kedaulatan rakyat ini kemudian terwujud dalam sistem demokrasi perwakilan.

Kusnardi dan Harmaily Ibrahim ${ }^{9}$ mengemukakan, rakyatlah yang dianggap sebagai pemilik dan pemegang kekuasaan tertinggi dalam suatu negara. Sebagai pemilik dan pemegang kekuasaan, rakyat menentukan corak dan cara pemerintahan diselenggarakan, serta menentukan tujuan yang hendak dicapai negara. ${ }^{10}$ Dalam UUD 1945, kedaulatan rakyat dilaksanakan melalui sistem perwakilan (representation). Jimly Asshidiqie menyatakan bahwa kedaulatan rakyat dengan sistem perwakilan atau demokrasi biasa juga disebut sistem demokrasi perwakilan (representative democracy) atau demokrasi tidak langsung (indirect democracy). ${ }^{11}$

Bagir Manan dengan mengutip pendapat Hatta tentang kedaulatan rakyat mengemukakan:

"kedaulatan rakyat berarti, bahwa kekuasaan untuk mengatur pemerintahan dan negara ada pada rakyat, rakyat yang berdaulat, berkuasa untuk menentukan cara bagaimana ia harus diperintah. Tetapi putusan rakyat yang menjadi peraturan pemerintah bagi orang semuanya ialah keputusan yang ditetapkan dengan cara mufakat dalam suatu perundingan yang teratur bentuk dan jalannya. Bukan keputusan yang sekonyong-konyong diambil dengan cara sendiri saja, dengan menyerukan bersama-sama "mufakat". Di sini tidak ada permusyawaratan terlebih dahulu, sebab itu bukanlah keputusan menurut kedaulatan rakyat".

Dalam perkembangannya rakyat menyelenggarakan kedaulatan yang dimilikinya melalui wakilnya. Para wakil rakyat inilah yang kemudian mewakili mayoritas rakyat melalui partai politik. Oleh karenanya masyarakat memberikan mandat kepada para wakilnya untuk mewakili kepentingannya dalam proses politik dan pemerintahan. Dapat dikatakan bahwa partai politik itu pada pokoknya memiliki kedudukan (status) dan peranan (role) yang sentral dan penting dalam setiap sistem kedaulatan rakyat. Partai politik biasa disebut sebagai pilar demokrasi (ada juga yang menyebut sebagai salah satu infrastruktur politik), karena mereka memainkan peran yang penting sebagai penghubung antara pemerintahan negara (the state) dengan warga negaranya (the citizen). ${ }^{12}$ Bahkan menurut Schattscheider "political parties created democracy", partai politiklah yang membentuk demokrasi, bukan sebaliknya. Namun, terdapat juga pandangan kritis terhadap partai politik

\footnotetext{
9 Kusnardi dan Harmaily Ibrahim, Pengantar Hukum Tata Negara Indonesia, (Jakarta: PSHTN FHUI, 1983), hlm.328.

${ }^{10}$ Jimly Asshidiqie, Pengantar Ilmu Hukum Tata Negara Indonesia, (Jakarta: Sekretariat Jenderal dan Kepaniteraan Mahkamah konstitusi, 2006), hlm.168.

${ }^{11}$ Ibid, hlm.328.

${ }^{12}$ Jimly Asshiddiqie, Pokok-Pokok Hukum,... Op. Cit, Hlm. 710
} 
yang menyatakan bahwa partai politik sebenarnya tidak lebih daripada kendaraan politik bagi sekelompok elit politik yang berkuasa.

Di sisi lain, Teori Kedaulatan hukum menyatakan bahwa yang memiliki kekuasaan tertinggi dalam suatu negara ialah hukum, karena itu baik raja, penguasa, dan rakyat serta negara sendiri tunduk terhadap hukum. Konsep kedaulatan ini kemudian melahirkan negara hukum yang mempunyai unsur utama bahwa setiap tindakan negara harus didasarkan pada hukum atau harus dapat dipertanggungjawabkan pada hukum.

Dalam konsep ini, kedudukan konstitusi dalam suatu negara hukum merupakan hal yang sangat penting karena hukum akan selalu berdasarkan konstitusi sebagai hukum tertinggi dalam suatu negara. Secara etimologi kata konstitusi adalah segala ketentuan dan aturan mengenai ketatanegaraan (Undang-Undang Dasar dan sebagainya), atau Undang-Undang Dasar suatu negara. Dengan kata lain, segala tindakan atau perilaku seseorang maupun penguasa berupa kebijakan yang tidak didasarkan atau menyimpang konstitusi, berarti tindakan tersebut adalah konstitusional. Adapun negara dipandang dari sudut kekuasaan dan menganggapnya sebagai organisasi kekuasaan, maka Undang-Undang Dasar dapat dipandang sebagai lembaga atau kumpulan asas yang menetapkan bagaimana kekuasaan dibagi antara beberapa lembaga kenegaraan, misalnya antara badan legislatif, eksekutif, dan yudikatif. Undang-Undang Dasar menentukan cara-cara bagaimana pusat-pusat kekuasaan ini bekerja sama dan menyesuaikan diri satu sama lain, Undang-Undang Dasar merekam hubungan-hubungan kekuasaan dalam suatu negara. ${ }^{13}$ Kedaulatan rakyat, konstitusionalisme, dan kedaulatan hukum (negara hukum) kemudian melahirkan apa yang disebut sebagai negara hukum berdasar pada demokrasi konstitusional.

\section{Konstitusi Sebagai Naskah Kedaulatan Tertinggi: Living Constitution atau Textualism}

Dalam negara hukum yang berdasar pada konstitusi, ketentuan konstitusional dalam konstitusi menjadi sesuatu yang supreme atau tertinggi karena ketentuan tersebut secara filosofis merupakan bentuk dari perjanjian masyarakat tertinggi. Dalam konstitusi tersebut terdapat hasrat masyarakat untuk menyerahkan sebagian kedaulatannya kepada negara. Dengan pengertian lain, konstitusi adalah manifestasi kedaulatan rakyat dalam sebuah naskah yang diberi bentuk hukum.

Istilah konstitusi sebenarnya sudah ada sejak zaman Yunani di mana terdapat Konstitusi Athena. Keberadaan Konstitusi Athena pada saat itu

13 Dahlan Thaib, Jazim Hamidi dan Ni'matul Huda, Teori dan Hukum Konstitusi, (PT Raja Grafindo, 1999), hlm. 9. 
dipandang sebagai alat demokrasi yang sempurna. ${ }^{14}$ Pada masa kekaisaran Romawi, istilah konstitusi digunakan untuk menyebut the act of legislation by emperor. ${ }^{15}$ Dalam kepustakaan Belanda istilah konstitusi dikenal dengan sebutan Grondwet atau undang-undang yang menjadi dasar dari segala hukum. ${ }^{16}$ James Bryce mendefinisikan konstitusi sebagai kerangka politik yang terorganisasi berdasarkan hukum mencakup di dalamnya kelembagaan negara dengan fungsi dan hak-hak yang jelas. C.F. Strong mendefinisikan konstitusi sebagai kumpulan prinsip-prinsip yang mengatur mengenai kekuasaan pemerintah, hak-hak warga, dan hubungan antara pemerintah dan warga.

Di Indonesia, tidak dipungkiri lagi bahwa konstitusi mempunyai fungsi dan kedudukan yang sangat fundamental dalam kehidupan berbangsa dan bernegara. Dalam konteks ini, Komisi Konstitusi tentang perubahan Undang-Undang Dasar Negara RI tahun 1945 menyimpulkan bahwa kedudukan dan fungsi konstitusi adalah sebagai berikut: ${ }^{17}$

1. Konstitusi berfungsi sebagai dokumen nasional (national document) yang mengandung perjanjian luhur, berisi kesepakatan-kesepakatan tentang politik, hukum, pendidikan, kebudayaan, ekonomi, kesejateraan, dan aspek fundamental yang menjadi tujuan negara;

2. Konstitusi sebagai piagam kelahiran negara baru (a birth certificate of new state). Hal ini juga merupakan bukti adanya pengakuan masyarakat internasional, termasuk untuk menjadi anggota PBB, karena itu, sikap kepatuhan suatu negara terhadap hukum internasional ditandai dengan adanya ratifikasi terhadap perjanjian-perjanjian internasional;

3. Konstitusi sebagai sumber hukum tertinggi. Konstitusi mengatur maksud dan tujuan terbentuknya suatu negara dengan sistem administrasinya melalui adanya kepastian hukum yang terkandung dalam pasal-pasalnya, unifikasi hukum nasional, social control, memberikan legitimasi atas berdirinya lembaga-lembaga negara termasuk pengaturan tentang pembagian dan pemisahan kekuasaan antara organ legislatif, eksekutif, dan yudisial. Konstitusi sebagai sumber hukum tidak saja berfungsi sebagai a tool of social engeneering dan social control, melainkan juga harus mampu merespon secara kritis perubahan zaman;

${ }^{14}$ Ahmad Sukardja, Piagam Madinah \& Undang-Undang Dasar NRI 1945, (Jakarta: Sinar Grafika, 2012), hlm. 34

15 Charles Howard McIllwain, Constitutionalism: Ancient and Modern, (Cornell University Press, 1947), hlm. 23.

${ }^{16}$ Ahmad Sukardja, op.cit, hlm. 36.

${ }^{17}$ Majelis Permusyawaratan Rakyat, Buku I, Naskah Akademik Kajian Komprehensip Komisi Konstitusi tentang Perubahan Undang-Undang Dasar Negara RI Tahun 1945, (Jakarta, 2004), hlm. 12-13. 
4. Konstitusi sebagai identitas nasional dan lambang persatuan. Konstitusi menjadi suatu sarana untuk memperlihatkan berbagai nilai dan norma suatu bangsa dan negara, misalnya simbol demokrasi, keadilan, kemerdekaan, negara hukum, yang dijadikan sandaran untuk mencapai kemajuan dan keberhasilan tujuan negara. Konstitusi suatu negara diharapkan dapat menyatakan persepsi masyarakat dan pemerintah, sehingga memperlihatkan adanya nilai identitas kebangsaan, persatuan dan kesatuan, perasaan bangga, dan kehormatan sebagai bangsa yang bermartabat. Konstitusi dapat memberikan pemenuhan atas harapanharapan sosial, ekonomi, dan kepentingan politik. Konstitusi tidak saja mengatur pembagian dan pemisahan kekuasaan dalam lembaga-lembaga politik seperti legislatif, eksekutif, dan, yudisial, akan tetapi juga mengatur tentang penciptaan keseimbangan hubungan (checks and balances) antara pemerintah di pusat maupun di daerah;

5. Konstitusi sebagai alat untuk membatasi kekuasaan. Konstitusi dapat berfungsi untuk membatasi kekuasaan, mengendalikan perkembangan dan situasi politik yang selalu berubah, serta berupaya untuk menghindari adanya penyalahgunaan kekuasaan. Berdasarkan alasan tersebut, menjadi sangat penting diperhatikan seberapa jauh formulasi Pasal-Pasal dalam konstitusi dalam mengakomodasikan materi muatan-muatan pokok dan penting sehingga dapat mencegah timbulnya penafsiran yang beraneka ragam;

6. Konstitusi sebagai pelindung HAM dan kebebasan warga negara. Konstitusi memberikan perlindungan terhadap hak-hak asasi manusia dan hak-hak kebebasan warga negara. Hal ini merupakan pengejawantahan suatu negara hukum dengan ciri-ciri equality before the law, nondiskriminatif dan keadilan hukum (legal justice) dan keadilan moralitas (social and moral justice).

Telah jelas bahwa konstitusi telah disepakati mempunyai kedudukan yang supreme dan merupakan naskah tertinggi dan fundamental. Konstitusi mempunyai legitimasi dari kedaulatan rakyat sebagai sumber dari kedaulatan suatu negara. Jimly Asshiddiqie ${ }^{18}$ menegaskan jika negara itu menganut paham kedaulatan rakyat, maka sumber legitimasi konstitusi itu adalah rakyat. Jika yang berlaku adalah paham kedaulatan raja, maka raja yang menentukan berlaku tidaknya suatu konstitusi. Hal inilah yang disebut oleh para ahli sebagai constituent power yang merupakan kewenangan yang berada di luar dan sekaligus di atas sistem yang diaturnya. Karena itu, di lingkungan negara-negara demokrasi, rakyatlah yang dianggap menentukan berlakunya suatu konstitusi. Di Indonesia telah jelas bahwa rakyatlah yang menentukan berlakunya suatu konstitusi.

\footnotetext{
${ }^{18}$ Jimly Asshiddiqie, Pengantar Ilmu Hukum Tata Negara Jilid I. Op.Cit. hlm. 117
} 
Ketika suatu konstitusi itu berlaku, maka konstitusi tersebut legitimate dan menjadi suatu sumber hukum tertinggi. Hal inilah yang menguatkan para pendukung aliran textualisme bahwa pengujian konstitusional tetap tidak bisa keluar dari rel teks konstitusi, terlebih lagi jika ketentuan konstitusi tersebut jelas dan tidak bisa ditafsirkan.

Yang menjadi pertanyaan kemudian, apakah penafsiran konstitusi dapat menjadi sarana perubahan konstitusi? Penafsiran merupakan metode untuk memahami makna yang terkandung dalam teks-teks hukum untuk dipakai dalam menyelesaikan kasus-kasus atau mengambil keputusan atas hal-hal yang dihadapi secara konkret. Di samping itu, dalam bidang hukum tata negara, penafsiran dalam hal ini judicial interpretation (penafsiran oleh hakim), juga dapat berfungsi sebagai metode perubahan konstitusi dalam arti menambah, mengurangi, atau memperbaiki makna yang terdapat dalam teks undang-undang dasar. ${ }^{19}$ Penganut aliran living constitution sangat mendorong judicial activism melalui penafsiran konstitusi sehingga konstitusi bisa mengikuti perkembangan zaman.

Namun demikian yang perlu diingat adalah penafsiran merupakan metode untuk mengetahui makna yang belum jelas pengertiannya dan penafsiran ini tidak berlaku ketika UUD 1945 telah jelas dalam pemaknaannya. Selain itu penafsiran yang menyimpang dari tekstual akan menjadikan pengujian konstitusional terkena counter majoritarian difficulty. ${ }^{20}$ Menurut pengusung counter majoritarian difficulty, hakimhakim konstitusi yang tidak dipilih langsung oleh rakyat kemudian membatalkan konstitusi dan legislasi yang dibentuk oleh lembaga perwakilan rakyat yang dipilih langsung oleh rakyat, keadaan ini adalah antidemokrasi. Dengan demikian, hakim-hakim tersebut tidak bisa diberikan kewenangan untuk menafsirkan kebijakan yang sesuai dengan keinginan rakyat serta kewenangan dalam menguji kebijakan-kebijakan yang bertentangan dalam berbagai situasi oleh institusi-institusi yang berlainan.

Selain itu, para pendukung capres perseorangan mengemukakan analogi calon kepala daerah independen yang secara konstitusional dibuka oleh Mahkamah Konstitusi untuk diterapkan terhadap calon presiden perseorangan. Dari sudut pengujian konstitusional, norma pengujian mengenai calon kepala daerah independen dan calon presiden perseorangan berbeda. Calon kepala daerah independen lahir dari konstruksi konstitusional pemilihan secara demokratis dalam Pasal 18 UUD 1945. ${ }^{21}$ Sementara itu

\footnotetext{
${ }^{19}$ Jimly Asshididiqie, Pengantar Ilmu Hukum Tata Negara, (Jakarta: Sekretariat Jenderal dan Kepaniteraan Mahkamah Konstitusi, 2006), hlm. 273.

${ }^{20}$ Alexander M Bickel, The Least Dangerous Branch: The Supreme Court at the Bar of Politics. (New Haven: Yale UP, 1986), hlm. 17-33.

${ }^{21}$ Gubernur, Bupati, dan Walikota masing-masing sebagai kepala pemerintah daerah provinsi, kabupaten, dan kota dipilih secara demokratis.
} 
mekanisme pengajuan calon presiden telah jelas tertuang dalam Pasal 6A UUD 1945.

Berkenaan dengan hal ini, sikap Mahkamah Konstitusi yang sangat berhati-hati dalam pengujian UU Pilpres No. 42 Tahun 2008 dapat dipahami dalam konteks menjaga agar tidak terkena kritik counter majoritarian difficulty serta menjaga agar tidak berbenturan dengan prinsip kedaulatan rakyat berdasarkan Undang-Undang Dasar.

Selain itu, penelitian di beberapa negara menunjukkan bahwa legitimasi Mahkamah Konstitusi diperoleh melalui proses waktu yang lama dan dapat diakselerasi melalui strategi kehumasan yang menjelaskan peranan dari Mahkamah Konstitusi tersebut dan alasan-alasan putusan-putusannya ${ }^{22}$. Pengalaman Amerika menunjukan bahwa sifat kenegarawanan peradilan dapat menjadi elemen utama yang sangat diperlukan dalam menumbuhkan legitimasi itu. Dalam putusannya di Marbury V Madison, Mahkamah Agung Amerika yang baru terbentuk mengakui bahwa, putusan yang banyak menuai perdebatan atau bahkan diabaikan akan berakibat pada masa depan pengadilan sebagai sebuah institusi itu sendiri. Pengadilan harus berhati-hati ketika menggunakan instrumen pengujian konstitusional dengan cara yang tidak frontal terhadap cabang-cabang kekuasaan lain. ${ }^{23}$

\section{Penutup}

Saat ini harapan rakyat terhadap partai politik kian rendah sebagaimana terlihat pada kemerosotan partisipasi pemilih dan sinisme atas kinerja elite di eksekutif dan legislatif. Dari partai politik sendiri, tidak tampak kesungguhan melakukan introspeksi beranjak menuju partai modern yang jelas program dan perekrutan kadernya. ${ }^{24}$ Di tengah-tengah apatisme terhadap partai politik saat ini, dan semakin dekatnya hajat nasional untuk memilih presiden yang bisa membenahi keadaan bangsa dan negara, wacana calon presiden perseorangan harus didorong melalui mekanisme yang mencerminkan negara hukum berdasarkan konstitusi yang demokratis. Melalui proses yang konstitusional, hasil yang didapat akan mencerminkan pembangunan konstitusionalisme yang sistematik, holistik, serta terarah dan bukan pembangunan konstitusionalisme yang sporadis dan pragmatik.

Dengan demikian, perlu didorong suatu perubahan konstitusi untuk membuka keran konstitusional bagi calon presiden perseorangan. Gagasan calon Presiden dan Wakil Presiden perseorangan itu dituangkan dalam draft

\footnotetext{
22 James L. Gibson, Gregory A. Caldeira, and Vanessa A. Baird. "On the Legitimacy of National High Courts," American Political Science Review 92(2): 343-358 (1998).

${ }^{23}$ Robert G McCloskey, The American Supreme Court, 2nd ed., (Chicago: University of Chicago Press, 1994).

${ }^{24}$ Suwidi Tono, Jalan Terjal Demokrasi, Harian Umum Kompas, 23 Januari 2013
} 
perubahan kelima Undang-Undang Dasar (UUD) 1945 yang disusun Dewan Perwakilan Daerah (DPD). Ketentuan tersebut diusulkan diatur dalam Pasal 6A Ayat (2) draft amandemen UUD yang berbunyi, "pasangan calon Presiden dan Wakil Presiden berasal dari usulan partai politik peserta pemilihan umum atau perseorangan". Apapun hasilnya, saya mempercayai bahwa proses yang konstitusional akan semakin mendekatkan bangsa Indonesia kepada konstitusionalisme.

\section{Daftar Pustaka}

\section{A. Buku}

Asshiddiqie, Jimly, 1994. Gagasan Kedaulatan Rakyat dalam Konstitusi dan Pelaksanaannya di Indonesia, PT Ichtiar Baru Van Hoeve. , 2006. Pengantar Ilmu Hukum Tata Negara Indonesia, Jakarta: Sekretariat Jenderal dan Kepaniteraan Mahkamah konstitusi.

Bickel, Alexander M., 1986. The Least Dangerous Branch: The Supreme Court at the Bar of Politics, New Haven: Yale UP.

Gibson, James L, Gregory A. Caldeira, and Vanessa A. Baird, On the Legitimacy of National High Courts, American Political Science Review 92(2): 343-358 (1998).

Hamzah, Fahri, 2010. Negara Pasar dan Rakyat, Faham Indonesia.

Kusnardi, Moh., dan Harmaily Ibrahim, 1988. Hukum Tata Negara Indonesia, Edisi Ketujuh, Jakarta: Pusat Studi Hukum Tata Negara FH UI dan CV Sinar Bakti. PSHTN FHUI. , 1983. Pengantar Hukum Tata Negara Indonesia, Jakarta:

Mahkamah Konstitusi, Naskah Komprehensip Perubahan Undang-Undang Dasar Negara Republik Indonesia 1945, 2008, Buku IV Kekuasaan Pemerintahan Negara Jilid 1, Sekretariat Jenderal dan Kepaniteraan Mahkamah Konstitusi.

Majelis Permusyawaratan Rakyat, 2004. Buku I, Naskah Akademik Kajian Komprehensip Komisi Konstitusi tentang Perubahan Undang-Undang Dasar Negara RI Tahun 1945, Jakarta.

McCloskey, Robert G., 1994. The American Supreme Court, 2nd ed, Chicago: University of Chicago Press.

Mclllwain, Charles Howard, 1947. Constitutionalism: Ancient and Modern, Cornell University Press.

Sukardja, Ahmad., 2012, Piagam Madinah \& Undang-Undang Dasar NRI 1945, Jakarta: Sinar Grafika. 
Thaib, Dahlan, Jazim Hamidi dan Ni'matul Huda, 1999. Teori dan Hukum Konstitusi, Jakarta: PT Raja Grafindo.

\section{B. Lain-lain}

Asshiddiqie, Jimly, Struktur Ketatanegaraan Indonesia Setelah Perubahan Keempat UUD Tahun 1945, Makalah Disampaikan Pada Seminar Pembangunan Hukum Nasional VIII Denpasar, 14-18 Juli 2003.

Tono, Suwidi, Jalan Terjal Demokrasi, Harian Umum Kompas, 23 Januari 2013. 